\title{
Italian migration policy and politics: exacerbating paradoxes
}

Andrew Geddes and Andrea Pettrachin, Migration Policy Centre, Robert Schuman Centre for Advanced Studies, EUI, Florence.

Andrew Geddes is Professor of Migration Studies and Director of the Migration Policy Centre at the European University Institute

Andrea Pettrachin is Research Associate at the Migration Policy Centre at the European University Institute

\begin{abstract}
Key political and legislative developments related to immigration in Italy in 2019 were crystallised, represented and powerfully mediated in public debate by the Sea-Watch incident, which was emblematic not only of the politicisation of immigration in Italy but also of underlying paradoxes. One paradox is that migration flows to Italy across the Mediterranean attracted huge political and media attention despite being much smaller than migration for family or employment reasons. Another is that Italians' attitudes to immigration have generally become more favourable, although issue salience has been persistently high with important political effects. The third is that, while ostensibly driven by the intention of reducing undocumented migration, Matteo Salvini's actions as Interior Minister may lead to its increase and feed the problems his actions are supposed to address. While paradoxes of these types are evident in other destination countries, the commitment and political will to resolve them has further diminished in Italy in 2019.
\end{abstract}

Keywords: Migration Politics, Migration Policies, Sea-Watch, Security Decree, Lega. 
Events and incidents can focus attention, but this attention can also be directed towards certain understandings of the underlying issues or problems. The Sea-Watch incident played such a role in 2019. Sea-Watch is a German NGO that has conducted search and rescue operations in the Mediterranean since 2015. On 12 June 2019, its boat Sea-Watch 3 rescued 53 migrants off the Libyan coast. The ship's captain, Carola Rackete, refused to disembark the rescued migrants in Tripoli, arguing that this could not be considered a 'safe harbour', and instead moved towards Lampedusa, considered as the 'closest safe harbour'. Two days later, the Italian government approved the first version of the Decreto Sicurezza Bis (Follow-up Security Decree), on the basis of which Interior Minister, Matteo Salvini, issued an administrative decree that banned Sea-Watch 3 from entering Italian waters. Sea-Watch made a complaint to the European Court of Human Rights, but the Court declined to intervene, despite calling on Italy to provide assistance to vulnerable migrants. On 28 June, five EU countries offered to take the rescued migrants. ${ }^{1}$ After a two-week standoff with the Italian authorities, on 29 June, Rackete decided to dock in Lampedusa, in defiance of Salvini's ban, arguing that the rescued migrants were exhausted. ${ }^{2}$ After disembarkation, Rackete was arrested for having broken the blockade. ${ }^{3}$ She was released a few days later. ${ }^{4}$ The Sea-Watch case further polarised the political debate on immigration and exacerbated tensions within the yellow-green coalition. ${ }^{5}$ The President of the Chamber of Deputies, Roberto Fico, criticised Salvini's stances, ${ }^{6}$ while a delegation of Partito Democratico (Democratic Party, PD) and left-wing MPs boarded the SeaWatch 3 , harshly criticising the Government. ${ }^{7}$ Over the following weeks, Salvini kept the Government's attention focused on the case of NGO ships, and the Lega (League) further increased its support in opinion polls. ${ }^{8}$ The Follow-up Security Decree was converted into law by Parliament, through a vote of confidence, in late July, a few days before the collapse of the yellow-green coalition. 
The Sea-Watch incident is emblematic of the ways in which immigration in Italy has been politicised in domestic politics and as a European issue, and was linked to key political and legislative developments related to immigration in 2019. The incident concluded the first eight months of 2019, which saw the politics of migration centred on Salvini's draconian security legislation (the Security Decree of December 2018 and the Follow-up Security Decree of June 2019) and an intense focus on Mediterranean boat crossings and their supposed NGO facilitators. Yet, asylum and refugees are a relatively small sub-section of total immigration to Italy and actually, by 2019, these flows had returned to historically low levels. The intensification of political debate about migration and huge media attention on asylum-seeking flows contrasts with the relative absence of migration policy. Despite a continued demand for migrant workers in some sectors of the Italian economy, routes for regular labour migration for non-EU migrants have been closed while 'unplanned' family migration continues at relatively high levels. The EU as a potential source of policy development has instead shifted from being a vincolo esterno (external constraint) (Dyson and Featherstone, 1996) and instead became a capro espiatorio (scapegoat). The structuring factors that underlie policy choices remain fairly consistent, while the political will to resolve them seems much diminished, and the negative representation of the EU fed into what has effectively become a 'stop migration' policy. The Sea-Watch case also demonstrates ownership of the immigration issue by the League. It is very clear that immigration was central to the League's rise in 2019 and to its reinvention as a more conventional European radical right party (Mudde, 2019) combining Euroscepticism with hostility to immigration. Salvini's political rhetoric, however, is sometimes decoupled from policy and its effects. As this article shows, an effect of the Security Decree is actually to generate greater undocumented migration, which may well exacerbate the sense of insecurity that fuels the politicisation of migration. 
A paradox can be understood as an ambiguous or contradictory statement or action. The paradoxes in Italian migration policy and politics relate to two underlying structural factors. The first is the pressure on external borders particularly associated with Mediterranean crossings, although there is clear evidence that these have reduced dramatically since 2016. The second is the continued demand for migrant workers in some sectors of the Italian economy such as domestic work and agriculture. These structural factors are mediated, as we show, by the effective absence of migration policy and by intensified politicisation marked by high issue salience and effective ownership of the immigration issue by the League. This politicisation can be understood as a marked change in policy dynamics from when Zincone (1998) characterised migration policy-making as effectively sheltered from wider public debate. Our argument is not for Italian exceptionalism: for all destination countries, immigration is a complex and highly diverse issue that presents real dilemmas and challenges, creating difficult policy choices that can lead to ambiguities or contradictions. Our argument is more specific and is that in 2019 we see a further - and probably wilful - weakening of the capacity to resolve key dilemmas, which predates the League's vertiginous political ascendance.

\section{Migration flows and patterns}

There are underlying ambiguities in Italian migration policy and politics that become evident when migration flows are assessed and that give rise to the paradoxes we discussed in the previous section. We are not arguing that ambiguities and paradoxes can be simply or easily resolved by some silver bullet, but, rather, that they represent tough political choices, policy dilemmas and trade-offs between openness and closure and access to rights that are not being

addressed. A likely outcome, we contend, is a further increase in undocumented migration to Italy (Zincone, 1998). This is highly unlikely to be resolved by Salvini's prima gli italiani (Italians first) rhetoric and security decrees if 'internal' labour market and societal factors 
continue to combine with 'external' demand for entry persistently to structure migration to Italy.

First, we can look at the distribution of migration to Italy viewed through the number of residence permits issued and the reasons for their issuance to see the disjunction between media coverage of migration and actual flows. In 2019, asylum-seeking migration flows across the Mediterranean, and the disembarkation of migrants rescued by NGO ships, generated endless political discussion and extensive media coverage. This is paradoxical when it is borne in mind that other numerically more important aspects of the debate on immigration in Italy are largely ignored. Figure 1 illustrates the number of residence permits issued in Italy since 2011, disaggregated by type of permit. It shows that family migration flows - i.e. flows of people who migrate due to new or established family ties - are much more significant than both asylum seeking and work flows.

Fig. 1. Residence Permits Issued in Italy.

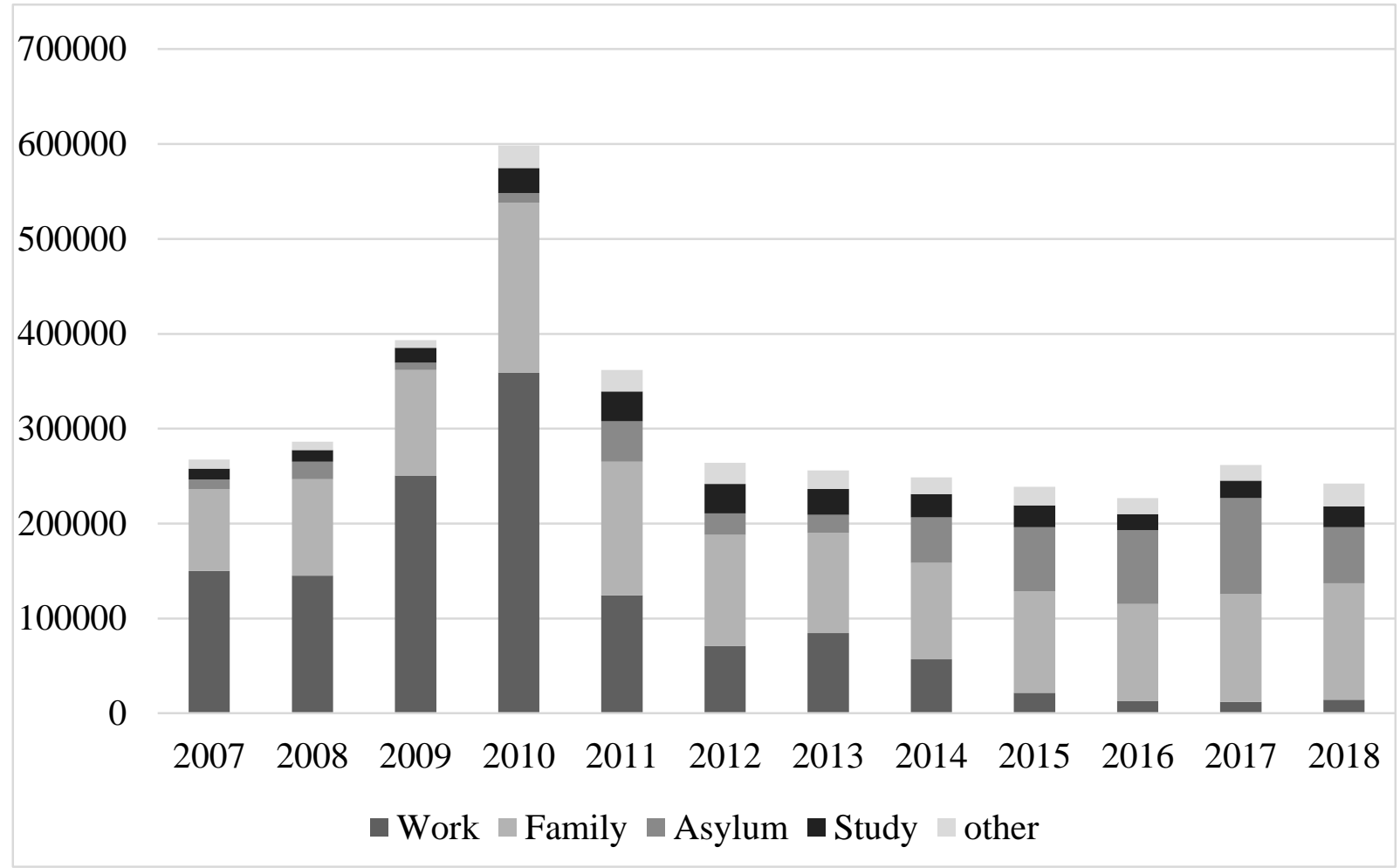

Sources: OECD, ISTAT. 
ISTAT data released in October 2019 on the numbers of residence permits issued in 2018 suggest that family migration flows remain stable. In contrast, the number of permits issued for asylum or for humanitarian reasons decreased by 42 per cent compared to 2017, which can be linked to the legislative developments described later in this article. Figure 1 also suggests that the number of work permits issued increased by 19.7 per cent in 2018 , but this was mainly due to conversion into work permits of visas for foreigners already residing in the country. Figure 2 shows the regional distribution of foreign residents in January 2019, disaggregated by type of residence permit.

Fig. 2. Foreign Residents in Italy in January 2019 (disaggregated by geographical area and type of residence permit).

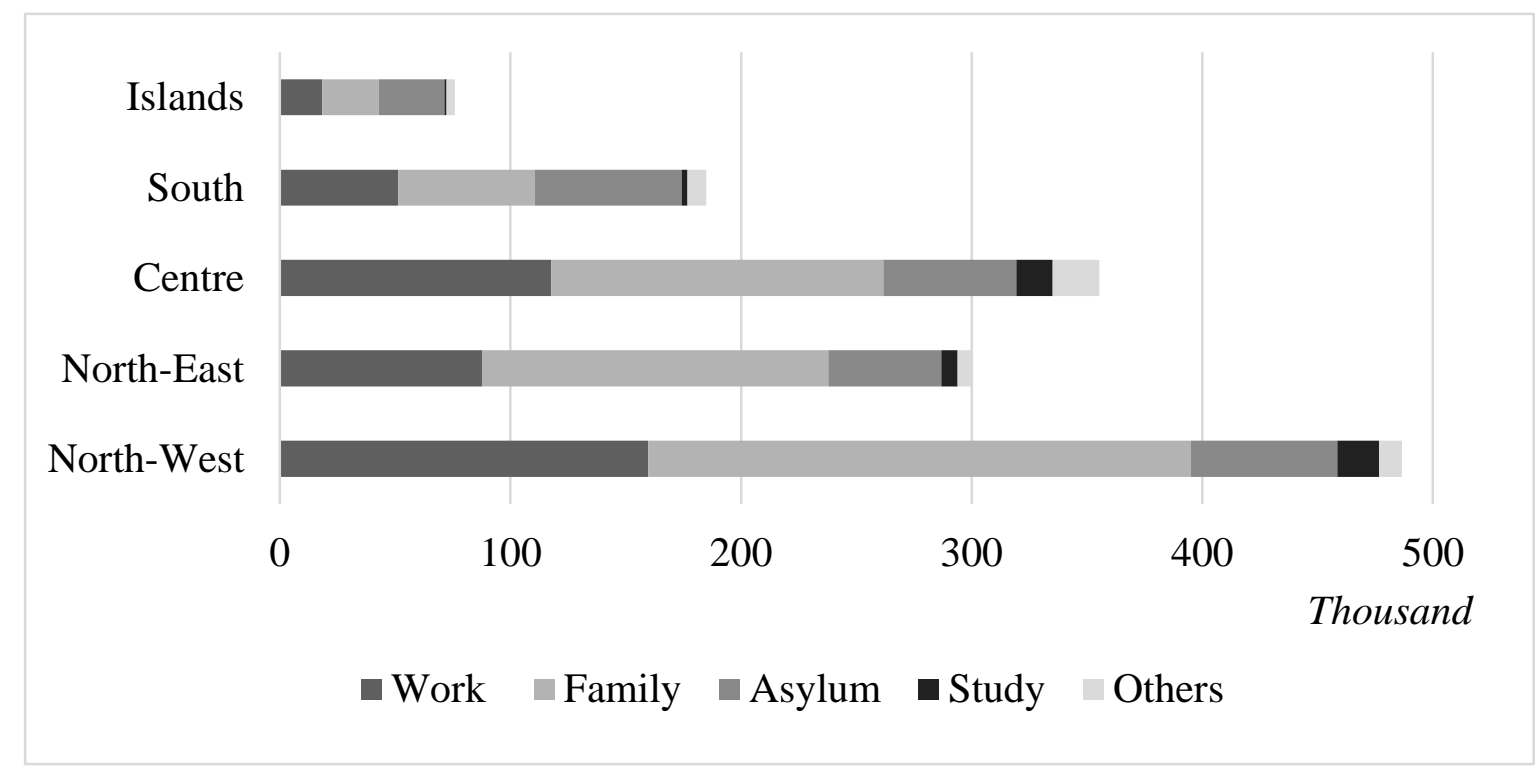

Source: ISTAT.

Figure 1 also suggests that labour migration is not a key route into Italy for non-EU migrants. Figure 3 looks back over the last 12 years to show work permits issued by the Ministry of the Interior according to its annual Decreto Flussi (Flows Decree), and the quota established for 2019. In February 2019, the Ministry of the Interior granted entry for work 
reasons to 30,850 migrants, despite the unheeded calls for more expansive labour migration policies from some leaders of Italian business organisations. ${ }^{9}$ This was the same number agreed by the centre-left governments in the previous four years.

Fig. 3. Quotas for non-EU migrant workers under the so-called Decreto Flussi.

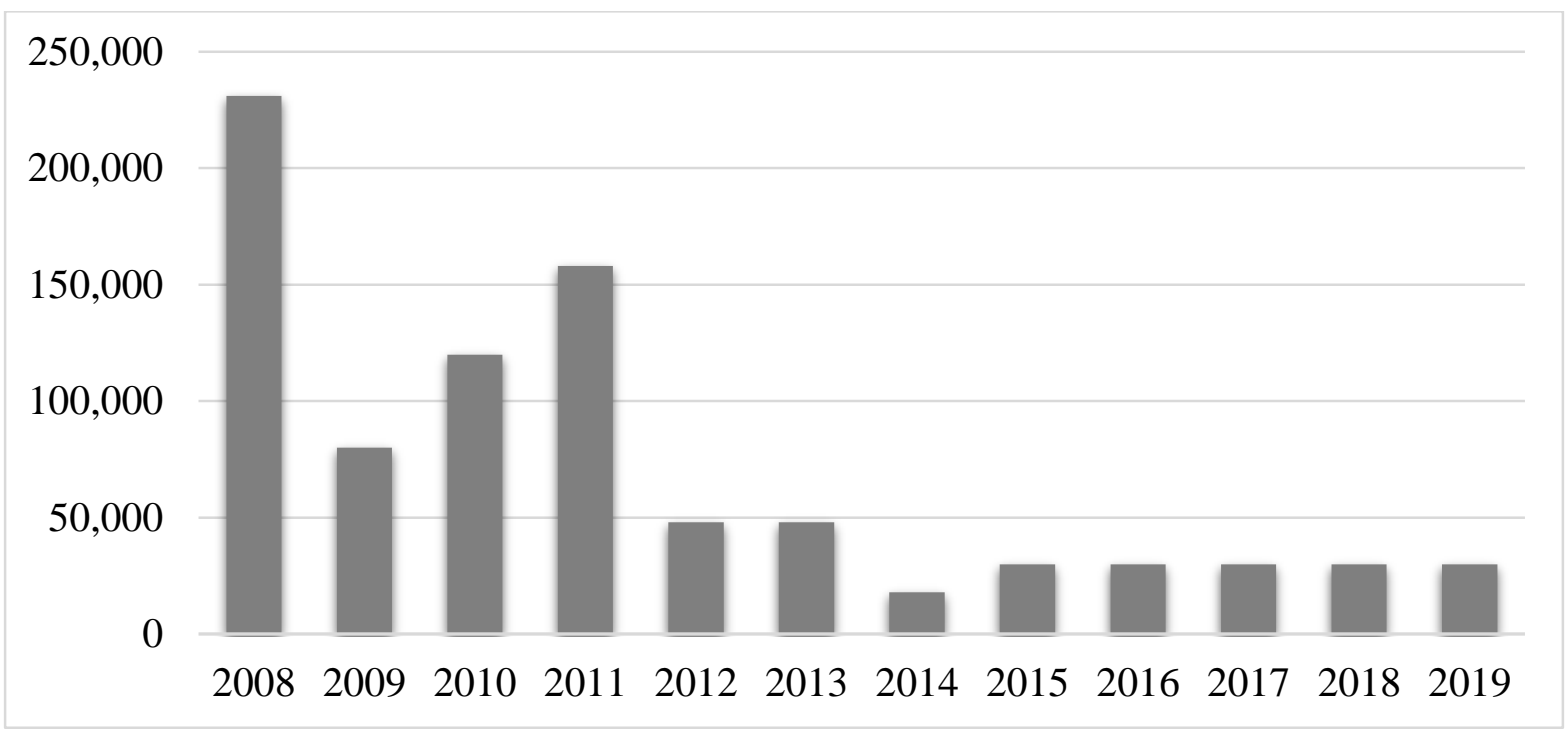

Sources: ISPI and Ministry of the Interior.

Research has shown that governments can seek to send 'control signals' targeted at 'unwanted' forms of immigration, such as asylum seeking, which creates space for more expansive policies for skilled labour migrants and that sending such signals can offer a successful way out of the 'immigration control dilemma' (Wright, 2014: 397). Italian governments are facing competing tensions between weak economic and labour market conditions, pressures for tighter immigration controls but also some demand for a more liberal approach to work visas in certain economic sectors from business organisations. However, it seems that they have sought to resolve the immigration control dilemma by effectively abandoning labour migration policies. There do, of course, remain routes for entry by citizens of other EU member states exercising their free movement rights that have contributed to a reduction in labour shortages in some sectors of the Italian economy. ${ }^{10}$ A continued demand 
for labour in key sectors such as agriculture and the care system has, in the absence of regular pathways, attracted undocumented migrants, ${ }^{11}$ particularly from Eastern Europe and North Africa. ${ }^{12}$ The solution to the problem might actually be better thought of as being part of the problem: significantly reduced routes for legal migration from outside the EU when combined with both a supply of migrants and demand for their labour can fuel irregular migration.

The extensive attention to the Central Mediterranean route for asylum-seeking migration could be seen as paradoxical because sea arrivals and asylum applications in 2019 had returned to historic, relatively low levels. As Figure 3 shows, after a peak of around 180,000 sea arrivals in 2016, these dramatically decreased in 2017 and 2018, after the Memorandum of Understanding between Italy and Libya, which led to close cooperation between Rome and the Libyan Coast Guard to attempt to stop migrant boats departing Libya. Sea arrivals further decreased in 2019: in the first ten months of 2019, 9,648 migrants arrived in Italy via the Central Mediterranean Route. Of these, only eight per cent were rescued by NGO ships, while 92 per cent reached Italy's shores autonomously. ${ }^{13}$ Since 2018 , the route has also become more dangerous, with a sharp rise in the proportion of migrants dying during the journey. ${ }^{14}$

As a consequence of these developments, in 2019 the number of asylum-seekers in the Italian reception system also started to decline. This represents a significant development, after five years during which the number of asylum applications was constantly higher than the number of asylum decisions. ${ }^{15}$ This also generated a huge backlog in Italy's asylum processing system. By December 2019, a total of 91,424 migrants were hosted within the Italian reception system, of which 67,036 asylum-seekers within initial reception centres and 24,388 migrants within the Sistema di protezione per titolari di protezione internazionale e per minori stranieri non accompagnati (Protection System for Beneficiaries of International Protection and Unaccompanied Foreign Minors, SIPROIMI), previously known as the Sistema di protezione 
per richiedenti asilo e rifugiati (Protection System for Asylum Seekers and Refugees, or SPRAR $).{ }^{16}$

Fig. 4. Sea arrivals and asylum applications in Italy 2008-2019.

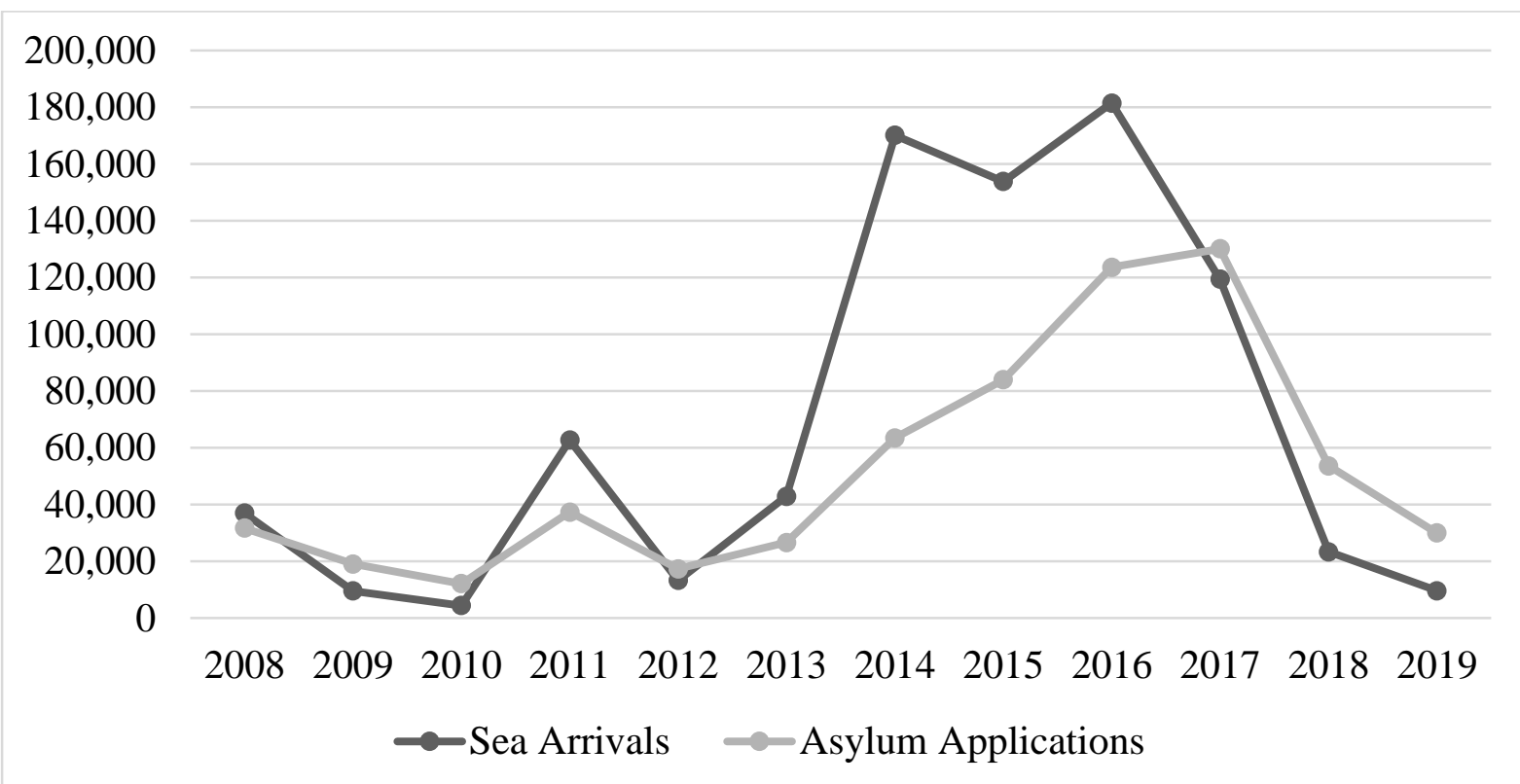

Note: Data for 2019 include sea arrivals until 31 October and an estimate of asylum applications based on data available until 31 July.

Source: Ministry of the Interior.

Interior ministry data for asylum applications issued in 2019 (Figure 4) show that in the past six years, there has been no correspondence between sea arrivals and asylum requests. Until 2017, asylum applications were at a much lower level than sea arrivals, because many migrants were not regularly identified and fingerprinted by the Italian authorities. Since late 2016, however, the identification rate has increased, and, in 2017, 99 per cent of migrants who entered the country were identified. ${ }^{17}$ In 2018 and 2019, conversely, asylum applications largely exceeded sea arrivals. This discrepancy is mainly due to so-called 'Dublin returnees', i.e. migrants sent back to Italy by other EU member states.

Looking more closely at the data reveals a further paradox: despite the focus of attention on the Mediterranean, in 2019 Italy was actually receiving more asylum-seekers from Germany than from Libya. This was a direct consequence of the EU's Dublin regulation, which meant 
that asylum-seekers that reached the EU via Italy and then travelled onwards to another member state could be sent back to Italy as the country of first arrival in the EU. In 2018, Italy received its highest ever number of 'Dublin transfers' (more than 6,300), despite Italy having accepted only a fraction of the people it was requested to take back. While only 1,200 migrants reached Italy from Libya in the first seven months of 2019, as Villa explains, in 2018 Germany alone sent 2,292 asylum-seekers back to Italy. ${ }^{18}$ Significantly, while keen to denounce its effects and to attack the EU, League MEPs did not participate in the 22 meetings in the European Parliament that formed part of the renegotiation of the Dublin regulation. ${ }^{19}$

\section{Political developments}

Having identified ambiguities and paradoxes both in terms of migration flows to Italy and how these have been mediated, we now move on to argue that these ambiguities and paradoxes have underlying political causes. Not the least of these is that immigration was central to the growth in support for the League, to Matteo Salvini's personal 'brand' as its leader, and to the rise of the League and Salvini to become the dominant political party and politician not only on the centre right but also in Italian party politics generally. Elections in 2019 provided clear evidence for this with the League securing 34.3 per cent of the vote at the May European Parliament elections plus successes at regional level, most notably in October 2019 in Umbria, where the League candidate, Donatella Tesei, backed by other centre-right parties secured 58 per cent of the vote. ${ }^{20}$

Immigration policy in Italy as in other European countries has been politicised, i.e. marked by high issue salience and polarisation (Hutter and Kriesi, 2019). There is evidence of how the centre right and centre left coalitions positioned themselves on the immigration issue prior to the repositioning of the League under Salvini's influence. Between 1995 and 2011, Urso (2018: 377-79) analysed left-right dimensions of the politicisation of immigration to 
identify it as a positional rather than a valence issue organised along two axes: securitarianhumanitarian and inclusive-exclusive. She concluded, however, that being in government tended to 'soften' the position of the centre right, which would frame arguments about immigration in pragmatic terms rather than in terms of moral principles or human rights (ibidem). Urso also contrasts left and right positions on immigration to show that different positions are taken towards different migrants, with asylum and labour migrants viewed as 'good migrants' while undocumented migrants and migrants from Islamic countries are viewed more negatively (ibidem).

As Interior minister, Salvini rejected pragmatism and attempted to translate tough rhetoric into policy targeted at asylum seekers and undocumented migrants. One factor behind this is that the moderating effects of more centrist coalition partners during the League's time in the various Berlusconi governments, were not evident during the 2018/19 yellow-green coalition when the immigration issue was effectively left to Salvini and the League (Geddes, 2008). Rather than being constrained by coalition dynamics, the League took advantage of the unclear position of the Movimento Cinque Stelle (Five-star Movement, M5s) on immigration, which mixed national securitisation and international humanitarianism (Mosca and Tronconi, 2019). Furthermore, by effectively owning the issue, the League seems to have significantly polarised the political debate on immigration. ${ }^{21}$

We now discuss attitudes to immigration and make a distinction between general attitudes and issue salience. Figure 5 shows that attitudes to both EU and non-EU immigrants have consistently become more positive since the 'migration crisis'. By June 2019 more Italians held a positive view of migration/free movement by EU citizens than a negative one, while the net negativity towards non-EU immigrants was significantly diminished. In both of these senses, Italian trends have been the same as pan-EU trends, albeit with a lower constant on both measures. 
Fig. 5. Italian and EU attitudes to immigration from outside the EU and other EU member states.

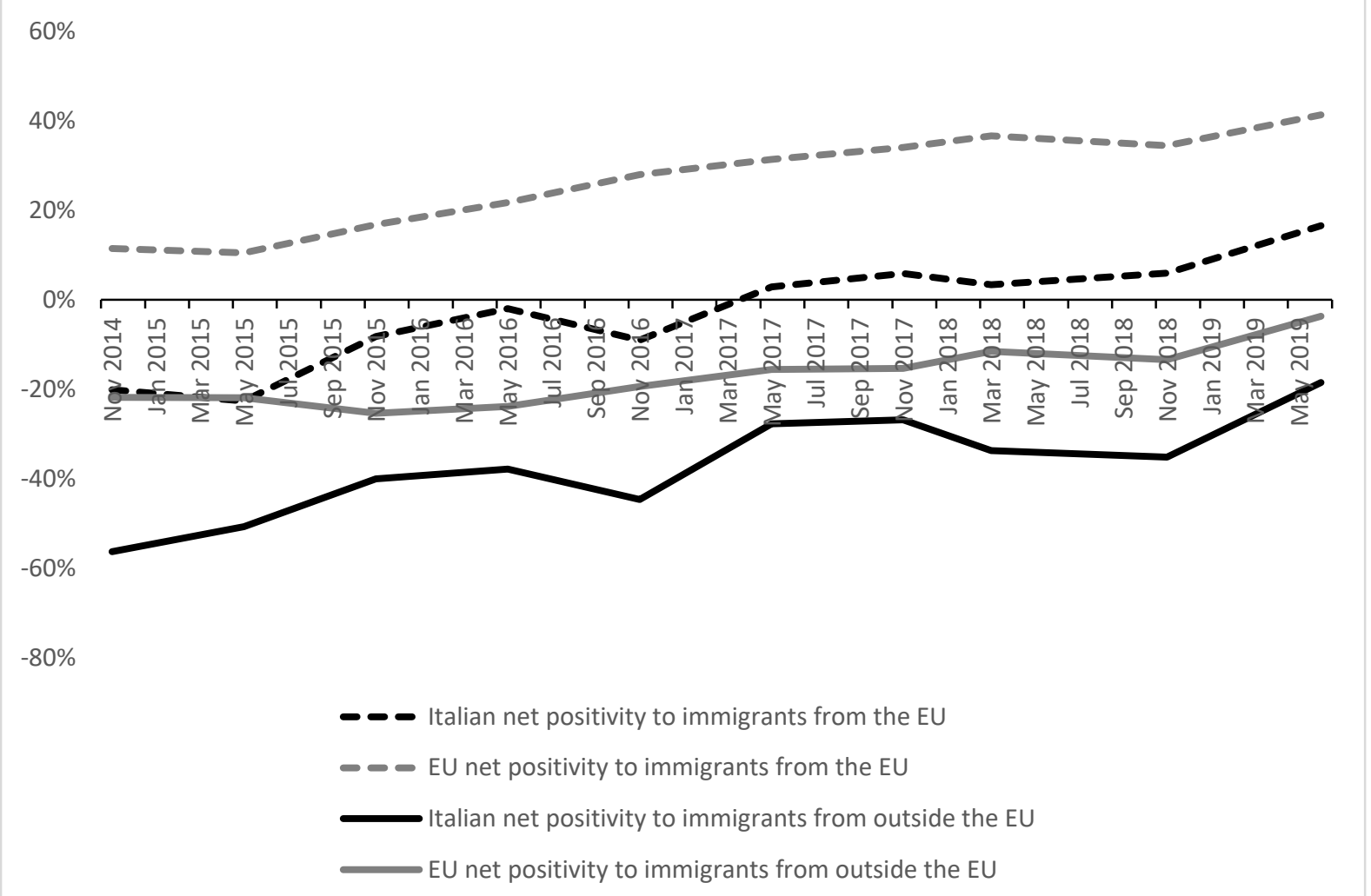

Note: Eurobarometer, 2014-2019. All 28 EU member states surveyed. Around 1,000 respondents per member state. "Please tell me whether each of the following statements evokes a positive or negative feeling for you. Immigration of people from other EU Member States / Immigration of people from outside the EU'. Net positivity $=$ Very positive + Fairly positive - Fairly negative - Very negative.

There is little evidence of attitudinal polarisation to intra- and extra-EU migration during the same period. In November 2014, responses regarding immigration of people from other EU member states had a standard deviation of 0.14. In June 2019, this had risen to 0.16: a minor change when compared to the change in net positivity. Second, the change in standard deviation of responses regarding 'immigration from outside the EU' did not change at all, staying level at 0.15 .

What did change was issue salience. Figure 6 shows that, between 2014 and 2019 the percentage of Italians stating that immigration is one of the two most important issues affecting their country increased markedly, from around 5 per cent to a peak of over 40 per cent in May 2017, before declining but still remaining relatively high. This figure for Italy followed a 
similar trajectory to the pan-European trajectory, until 2016 when the public salience of immigration began to climb again. We conclude that the 'migration crisis', in the Italian popular mindset, has lasted longer than elsewhere in Europe. We can also see that when Italians are asked about the most important issue affecting the EU - rather than their own country they are more likely to respond 'immigration', a common trend across Europe (Eurobarometer, 2014-2019). We can also see that the increase in the League's vote share has followed the salience of immigration, a trend that has been noted across Western Europe (Dennison, 2019; Dennison and Geddes, 2019). In a recent analysis published by YouTrend, ${ }^{22}$ Bailo analysed the salience of immigration in Salvini's Twitter account, media attention to immigration, and the vote share for the League in available opinion polls in 2019. He crucially shows that Salvini took advantage of his position of Minister of the Interior to keep media attention on the immigration issue high, and that this had an impact on voting intentions for his party. Remarkably, the analysis shows that media attention was driven more strongly by Salvini's Twitter activity than by the disembarkation of migrants from NGO ships in Sicily.

Survey research, by the Migration Policy Centre at the European University Institute, in Italy and seven other European countries, shows that Italians resist simple openness versus closure binaries. Rather, they tend to favour limits on territorial access (such as quotas on numbers of asylum applicants) and restrictions on rights (such as access to the labour market or family reunion) (Jeannet et al., 2019).

Given the strong geographical aspect to both voting - with the League still doing far better in the North - and migration - predominantly in the centre and North but with boat landings in the South - we also consider how attitudes and salience vary by region. IPSOS data show that southern Italians have more negative views of immigrants (Dixon et al. 2018: 80), both those from within and outside Europe, 'contrary to common perceptions that northern Italians are more anti-immigration than those in the south' (ibidem). 
Fig. 6. The salience of immigration amongst Italian and European citizens and the national and European Parliament election vote shares of the Lega Nord, 2008-2019.

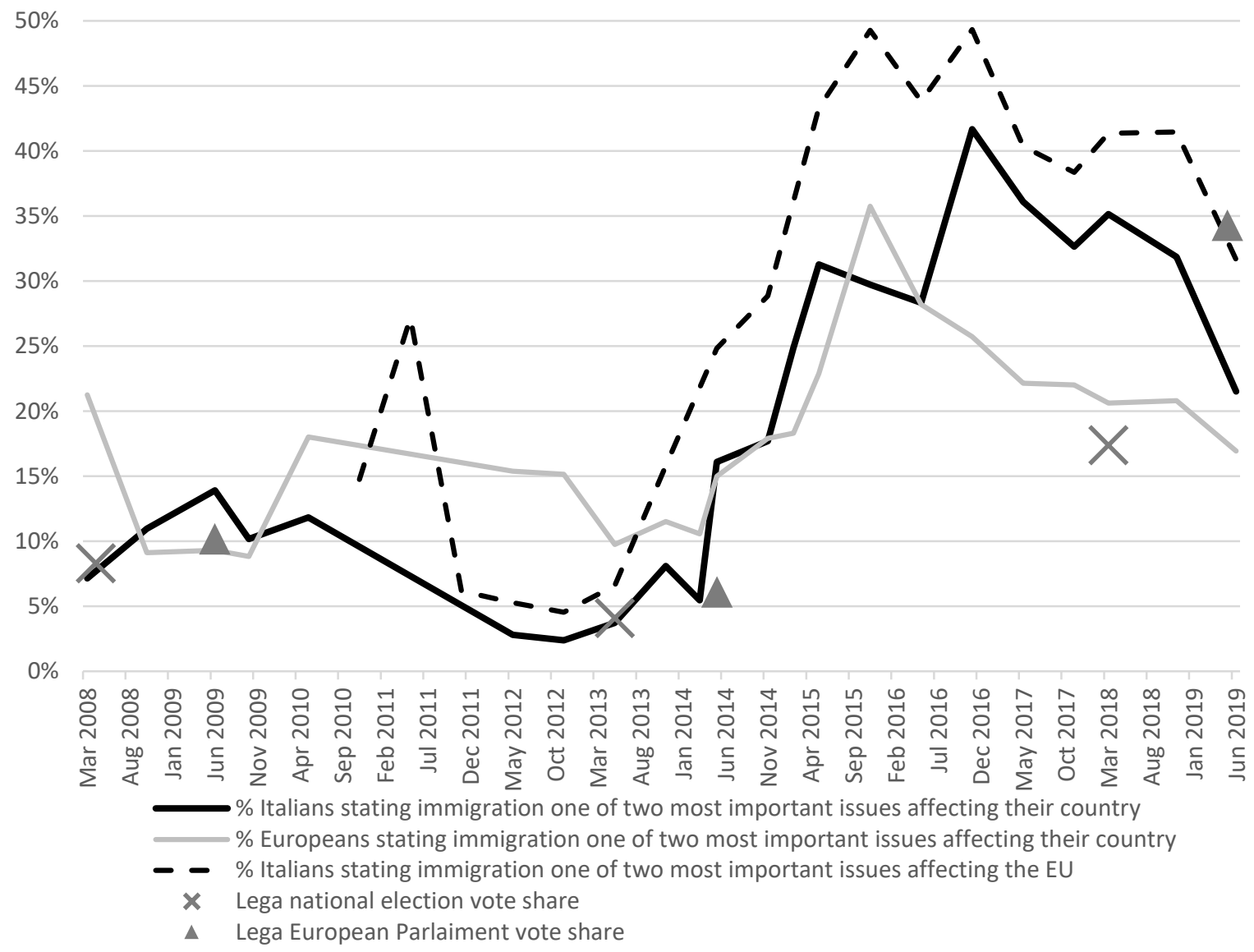

Note: Eurobarometer, 2009-2019. All 28 EU member states surveyed. Around 1,000 respondents per member state. "What do you think are the two most important issues facing (our country/the EU) at the moment?".

Despite this, Figure 7 shows that the salience of immigration in November 2018 was higher in the North (a trend that had been more noticeable in the past). This seemingly incongruous trend actually reflects those across Europe and it is partially due to the ordinal nature of the salience question: the lower salience of immigration in the South is also an effect of the far higher relevance of unemployment there. Again, as figure 7 shows, the salience of immigration at the regional level in November 2018, is correlated with the EU election vote shares of the League. 
Fig. 7. The salience of immigration across Italian regions (horizontal axis) and the European Parliament election vote shares of the Lega (vertical axis)

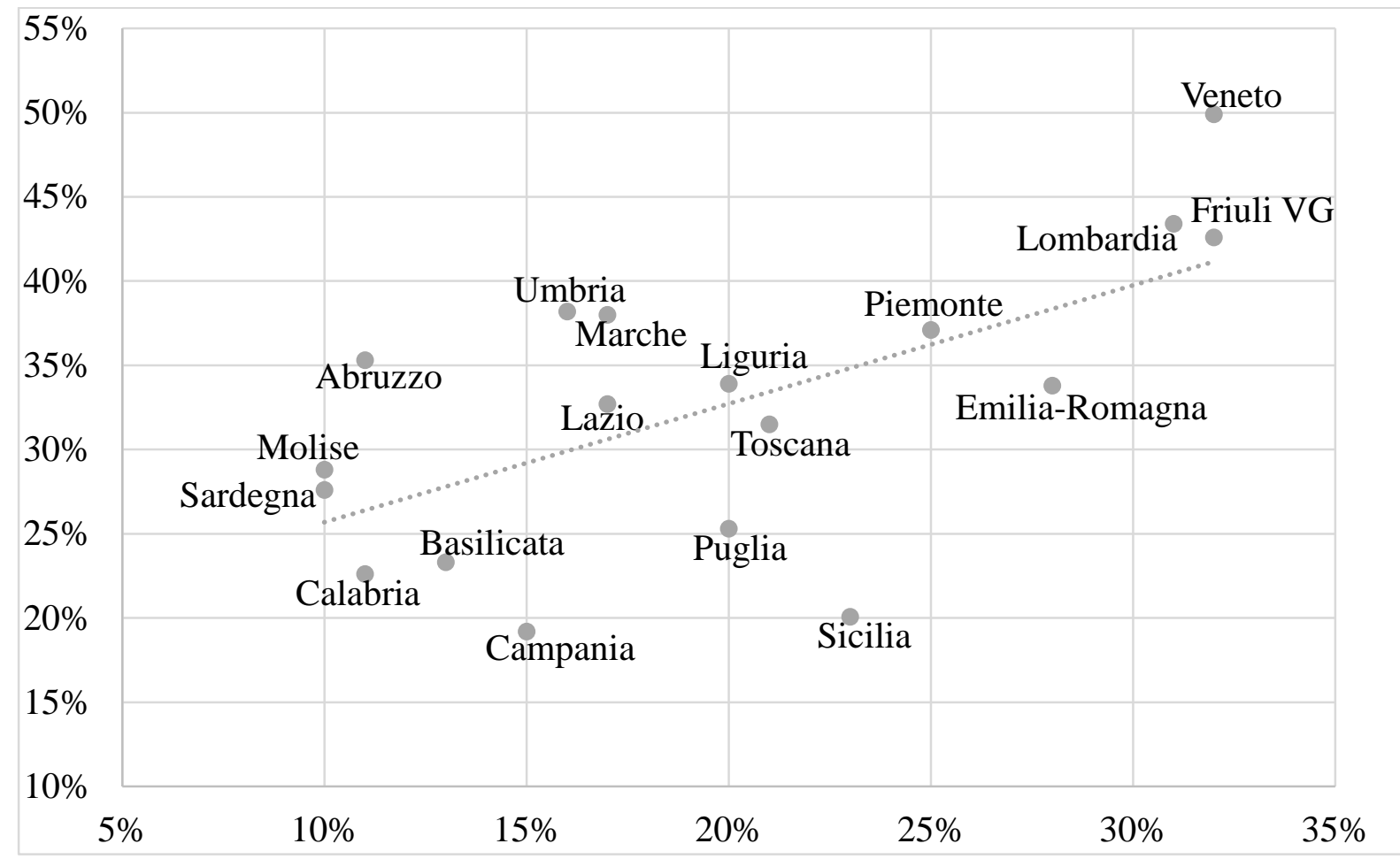

Note: Flash Eurobarometer, 2018. "What do you think are the two most important issues facing our country at the moment?".

Eurobarometer data also show that the long-standing tendency of Italians to be far more dissatisfied with their democracy than are other Europeans remains the case today, being both a cause and effect of the highly fragmented and volatile party system. Finally, Italians have a less positive image of the EU than other Europeans. The EU dimension to this has been key and representative of the hardening of opinion in Italy towards the EU in recent years. Salvini's election as party leader was driven more by hostility to the EU than to immigration although it is clearly the case that there have been higher political pay-offs from opposition to immigration than from high-risk ideas about exiting the single currency.

\section{Legislative developments}

2019 was a year of significant legislative development by the Conte I government, including the Security Decree and Follow-up Security Decree. ${ }^{23}$ Both were represented by Interior 
Minister Salvini as being aimed at 'increasing Italians' security' ${ }^{24}$ It has also been argued that the decrees had the side effect of actually boosting the 'production of undocumented migration', which the legislation professed to target. ${ }^{25}$ This could be seen as a decoupling of political rhetoric and policy outputs that serves to exacerbate the paradoxes associated with migration patterns and flows of migration that we identified earlier.

Decree Law 113/2018 (known as the Security Decree), implemented by Law 132/2018, radically reformed Italian policies on the status-determination process and asylum-seekers' reception. The key provision was the abolition of 'humanitarian protection' (grounded in Article 10 of the Italian Constitution), a form of protection that granted sanctuary to vulnerable groups of migrants that could not meet the criteria for refugee status or subsidiary protection. The humanitarian permit represented the most common form of protection granted to asylumseekers until 2017 (Figure 8, below) and gave recipients the right to work, and access to basic services. According to the League, the humanitarian permit was 'too uncertain' and left 'excessively wide margins for extensive interpretation'.${ }^{26}$ Under the Security Decree, therefore, it was replaced by 'special permits' of variable length for certain categories: asylum-seekers in need of medical care, victims of domestic violence or labour exploitation, asylum-seekers arriving from countries in a temporary situation of disaster, and asylum-seekers who distinguished themselves through acts of civic valour. Crucially, most of these 'special permits' last one year and cannot be converted into a residence permit, thus ensuring that migrants' positions in the country remain extremely precarious in both the short and long term. Other provisions of the decree introduced a 'procedure for manifestly unfounded asylum claims'; a list of 'safe countries of origin', whose nationals would be required to demonstrate 'serious reasons' for seeking protection, and provisions revoking international protection for migrants who commit a number of crimes or who return without 'serious and provable reasons' to their countries of origin (Corsi, 2019). 
The Security Decree radically redesigned the Italian reception system, by replacing the SPRAR with the SIPROIMI. Until 2018, the SPRAR system was the official reception system for asylum-seekers, created around small reception structures directly managed by local councils, in cooperation with the Ministry of the Interior. Although the system hosted only a limited number of asylum-seekers and never expanded beyond a critical threshold - mainly due to the reluctance of many local authorities to join the network - it was largely considered an example of 'best practice', and was designed to provide reception but also integration services (Marchetti, 2016). The Security Decree limited access to the SIPROIMI system only to beneficiaries of international protection.

The decree also transformed the Centri di Accoglienza Straordinaria (Extraordinary Reception Centres, CAS) system - the emergency reception system managed by the Prefectures and designed to provide initial assistance to asylum-seekers who could not be hosted in the SPRAR network - into a new official reception system for asylum-seekers. As many NGOs represented at the Tavolo Asilo Nazionale (National Asylum Roundtable) pointed out, this change had the effect of prioritising large, collective reception centres, which offered significantly lower reception standards and did not provide integration services such as language and vocational training courses (ibidem). Other provisions created new Territorial Commissions for the determination of asylum status, and prolonged the maximum length of detention periods for undocumented migrants within the Repatriation Centres.

Decree Law 53/2019 (known as the Follow-up Security Decree), implemented by Law $77 / 2019$, focused on access by asylum-seekers to Italian territory. Its main aim was to toughen sanctions on NGO ships seeking to bring migrants rescued in the Mediterranean to Italy. NGOs were accused of being a 'pull factor' attracting undocumented migration to Italy. The decree crucially states that the Interior Minister 'may restrict or prohibit the entry, transit or docking of ships in Italian territorial waters' for reasons of order and security, including cases where it 
is assumed that the crime of 'aiding illegal immigration' has been committed. According to the decree, if captains of NGO ships involved in search and rescue operations enter Italian waters without authorisation, they can be arrested, fined up to $€ 1$ million, and have their ships confiscated. The decree also allocates additional funds to National Prosecutors' Offices with the aim of fostering their action to tackle activities facilitating irregular immigration.

Both security decrees encountered widespread opposition from a large number of actors, including civil-society organisations but also local and regional governments and international organisations. The first decree was vehemently contested by several centre-left and left-wing mayors who refused to implement some of its provisions. The Mayors of Palermo, Naples and Florence (among others) decided to push through applications by migrants seeking residency on humanitarian grounds.$^{27}$ Civil Tribunals in Florence and Bologna, in May 2019, confirmed that asylum-seekers and beneficiaries of humanitarian protection were legally residing in the country and therefore had the right to be registered by the municipality. ${ }^{28} \mathrm{~A}$ few days later, the European Court of Justice also ruled against Article 7 of the Security Decree, confirming the prohibition on deporting a refugee whose international protection had been revoked, if they were at risk of persecution in their country of origin. ${ }^{29}$

The Follow-up Security Decree also elicited concern from President Sergio Mattarella, who, while promulgating the conversion law, raised two issues about its content in a letter to the speakers of the Chamber of Deputies and the Senate. ${ }^{30}$ First, he observed that the decree should not undermine in any way the obligation on sailors to rescue people in danger at sea. Second, he noted that the high fines imposed by an administrative act of up to $€ 1$ million on the captains of ships that transported rescued migrants was disproportionate and likely to be unconstitutional. The Council of Europe also expressed reservations about the decree, ${ }^{31}$ while the UNHCR called on the Italian government to 'reconsider' the bill saying: 'it would penalise rescues at sea'. ${ }^{32}$ The PD and its allies expressed strong opposition to the decree and, during 
the negotiations that led to the creation of the Conte II Cabinet announced that changing the decree would be a priority of the yellow-red coalition. ${ }^{33}$ By December 2019, these intentions had not been translated into action.

Crucially, a few days after the conversion into law of the Follow-up Security Decree, the Regional Administrative Tribunal of Lazio overturned the administrative act through which, in accordance with the decree, the Minister of the Interior had banned the NGO ship Open Arms from entering Italian waters. The Tribunal ruled that the vessel could enter Italian waters, after establishing that the situation on board, according to expert medical and psychological assessments, constituted an emergency. ${ }^{34}$ While the ruling of the Rome Tribunal significantly undermined the decree's effects it did not undermine its main provisions.

One year after its conversion into law, it is possible to argue that the Security Decree has had very significant effects on the Italian asylum system, the main one being that it has led to a significant increase in the number of undocumented migrants as a consequence of the abolition of humanitarian protection. This led to an increase in the number of rejections of asylum claims by 25 per cent in 2019 compared to 2018 (Figure 8). As a consequence of the decree, a total of 40,000 potential beneficiaries of humanitarian protection have seen their asylum applications rejected. ${ }^{35}$

Considering the current deportation rate, it has been forecast that, by the end of 2020 , 138,000 more migrants will not have any legal status, around half of whom will be undocumented because of the effects of the Security Decree (ibidem). This is likely to create problems for law and order, since undocumented migrants are more likely to commit crimes than regular migrants and migrants' crime rates tend to decrease with their social integration. ${ }^{36}$ 
Fig. 8. Asylum Decisions in Italy from 2014 to October 2019.

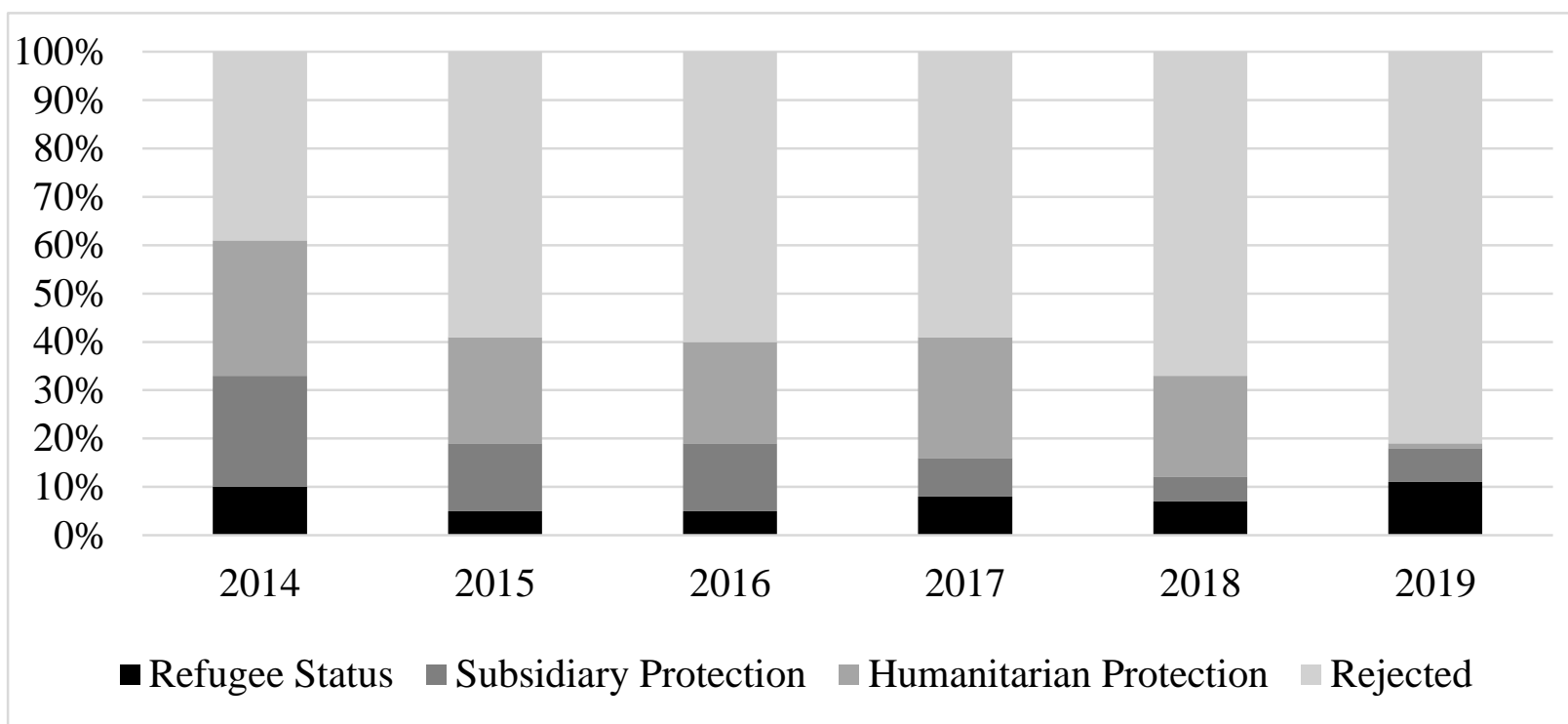

Source: Ministry of the Interior.

Fig. 9. Irregular Migrants in Italy and the impact of the Decreto Sicurezza.

$$
700,000
$$

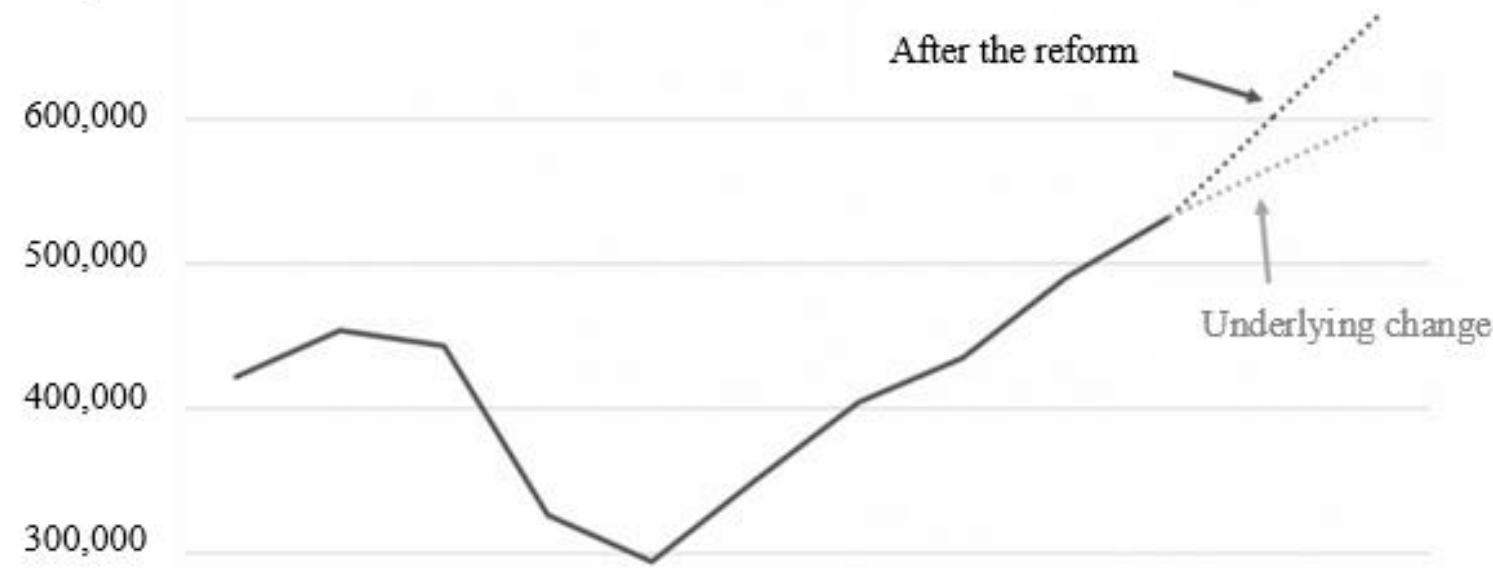

200,000

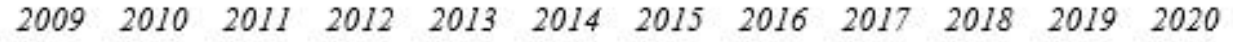

Source: $\operatorname{ISPI}^{37}$.

A Deputy Mayor affiliated to the M5s interviewed by one of this article's authors in early 2019 drew out very well the implications of the Security Decree for his municipality, and 
the potential political implications of the increase in the number of undocumented migrants in the country:

I keep asking myself if at the national level they considered the implications of these provisions, because I think a likely outcome of all this [the Security Decree] will be a sort of loop, which will produce negative effects for citizens' security (...). We'll have an increase in crimes, and an increased perception that immigrants are a problem. The loop is this one. You create a problem, and then you denounce and exploit its effects. It's a great instrument for the right, because it will become much harder to convince citizens of the positive effects of migration, and much easier for them to frame immigrants as a problem (...) if the security problems will become paradoxically objective and not deniable. And all those citizens who will feel more insecure and will not be in a position to make an in-depth analysis of the causes of this situation, whom do you think they will blame? Certainly not the Security Decree (Interview with city deputy mayor from the M5s, January 2019).

Salvini repeatedly declared that the Security Decree was aimed at fostering Italians' security. This is consistent with a well-established finding of research on decision-making, showing that political organisations in complex environments often tend to reach some kind of 'symbolic accord' with their environment that merely reflects inconsistencies without resolving them (Brunsson, 2000). In the migration field, a decoupling has consistently involved 'tough talk on immigration' with 'less focus on regulation of the domestic labour market' (Geddes and Boswell, 2011). In the case of the Security Decree we can observe a decoupling of the League's policy practices and their effects and the very rhetoric behind it.

\section{Conclusion.}


This article has explored some underlying paradoxes that can probably best be understood as more general characteristics of migration policy, but that have acquired particular force and relevance in Italy. We do not argue that these are exclusive to Italy, although there are, of course, highly specific circumstances in which these play out, conditioned by factors such as the experience of immigration and of immigration types, legal and institutional developments and, most importantly for our analysis, political developments. Our argument has been more specific and has contained two, linked, elements. First, the capacity and will to resolve key dilemmas has diminished and pre-dates the League's ascendance. Second, the 'immigration' issue, albeit narrowly focused on boat arrivals, has served as a proxy for significant change in Italian party politics, and is a key factor explaining the League's rise in 2019 . This, despite a dip in the immediate aftermath of the collapse of the yellow-green coalition subsequently recovered to leave the League as the dominant Italian political party, representing an archetypal radical-right party that belies centre-right labels. We also suggested that a direct effect - it is hard to know whether it was specifically intended or not - has been to create and exacerbate the irregular migration and criminality that were the target of the security decrees. Again, while intentions are difficult to prove, this is likely directly to benefit the League, which has acquired effective ownership of the immigration issue.

The replacement of the M5s-League coalition with the yellow-red government opened the possibility for a recasting of relations with the EU on migration issues, and for a reform of Salvini's security legislation. However, at the time of writing, the declared intentions to amend the Follow-up Security Decree have not been translated into action.

\section{References}

Brunsson, N. (2000), The Irrational Organization: Irrationality as a Basis for Organizational Action and Change, Bergen: Fagbokforlaget. 
Corsi, C. (2019), Evaluating the Salvini Decree: Doubts of Constitutional Legitimacy, Policy Brief 2019/6, European University Institute, Migration Policy Centre.

Dennison, J. (2019), Impact of Public Attitudes to Migration on the Political Environment in the Euro-Mediterranean Region, Working Paper, European University Institute. Technical Report, EUI RSCAS, Migration Policy Centre.

Dennison, J. and A. Geddes (2019), 'A Rising Tide? The Salience of Immigration and the Rise of Anti-Immigration Political Parties in Western Europe', Political Quarterly 90(1): $107-16$.

Dixon, T. et al. (2018) Attitudes towards National Identity, Immigration and Refugees in Italy. More in Common Report. http://www.moreincommon.com/.

Dyson, K. and K. Featherstone (1996), "Italy and EMU as a "Vincolo Esterno": Empowering the Technocrats, Transforming the State', South European Society and Politics 1(2): 272-99.

Geddes, A. (2008), 'Il Rombo Dei Cannoni? Immigration and the Centre-Right in Italy', Journal of European Public Policy 15(3): 349-66.

Geddes, A. and C. Boswell (2011), Migration and Mobility in the European Union. Basingstoke, Palgrave Macmillan.

Hutter, S. and H. Kriesi (2019), European Party Politics in Times of Crisis, New York: Cambridge University Press.

Jeannet, A., E. Ademmer, M. Ruhs, and T. Stöhr (2019) What Asylum and Refugee Policies Do Europeans Want? Evidence From a Cross-National Conjoint Experiment, EUI Working Paper, RSCAS Series 2019/73. 
Marchetti, C. (2016), 'Le Sfide Dell'accoglienza. Passato e Presente Dei Sistemi Istituzionali Di Accoglienza per Richiedenti Asilo e Rifugiati in Italia', Meridiana 86: 121-43.

Mosca, L., and F. Tronconi (2019), 'Beyond Left and Right: The Eclectic Populism of the Five Star Movement', West European Politics, 42(6): 1258-83.

Mudde, C. (2019), The Far Right Today, Cambridge: Polity Press.

Urso, O. (2018), 'The Politicization of Immigration in Italy. Who Frames the Issue, When and How', Italian Political Science Review/Rivista Italiana di Scienza Politica 48(3): 36581.

Wright, C.F. (2014), 'How Do States Implement Liberal Immigration Policies? Control Signals and Skilled Immigration Reform in Australia', Governance 27(3): 397-421.

Zincone, G. (1998), 'Illegality, Enlightenment and Ambiguity: A Hot Italian Recipe', South European Society and Politics 3(3): 45-82.

\footnotetext{
1 'Sea Watch si allontana su ordine Gdf. Farnesina: 'Ok di Paesi Ue ai ricollocamenti'. Indagata la capitana Carola Rackete', www.ilfattoquotidiano.it, 28 June 2019, accessed 8 January 2020.

${ }^{2}$ L. Tondo, 'Migrant Rescue Ship Defies Salvini's Ban to Enter Italian Port', www.theguardian.com, 26 June 2019, accessed 8 January 2020.

${ }^{3}$ E. Povoledo, 'Italy Arrests Captain of Ship That Rescued Dozens of Migrants at Sea', www.nytimes.com, 29 June 2019, accessed 8 January 2020.

${ }^{4}$ F. Tonacci and A. Ziniti, 'Sea-Watch, Carola Rackete è libera: "Commossa". Gip annulla l'arresto: 'Agì per portare in salvo i migranti'. L'ira di Salvini', www.repubblica.it, 2 July 2019, accessed 8 January 2020.

5 'Sea Watch, Farnesina annuncia accordo con Paesi Ue per la redistribuzione', www.huffingtonpost.it, 28 June 2019, accessed 8 January 2020.

6 'Sea Watch, Farnesina annuncia accordo con Paesi Ue per la redistribuzione', www.huffingtonpost.it, 28 June 2019, accessed 8 January 2020.

${ }^{7}$ M. Rubino, 'Sea Watch, l'ex M5s De Falco difende la capitana. Salvini: “Arrestatela", www.repubblica.it, 27 June 2019, accessed 8 January 2020.

${ }^{8}$ Youtrend, 'Il consenso dei partiti, dopo la vicenda Sea Watch', www.agi.it, 5 July 2019, accessed 8 January 2020.

${ }^{9}$ R. Querzé, 'Governo, il no Confindustria alla Flat Tax e alle frontiere chiuse ai migranti', www.corriere.it, 19 May 2019, accessed 8 January 2020. F. Baraggino, 'Industriali al governo: servono più migranti’, www.ilfattoquotidiano.it, 23 September 2019, accessed 8 January 2020.
} 
${ }^{10}$ There is a de facto migration policy for EU migration.

${ }^{11}$ Typically, these migrants enter the country with a visa and end up being illegal.

${ }^{12}$ D. Mancino, 'In Italia gli immigrati irregolari sono meno della media europea. La fotografia', www.infodata.ilsole24ore.com, 9 August 2019, accessed 8 January 2020. Corrado, A. et al. (2018). Is Italian Agriculture a 'Pull Factor' for Irregular Migration - and, If so, Why?, Open Society, European Policy Institute Report, retrieved from: http://cadmus.eui.eu//handle/1814/60950 (accessed 8 January 2020).

13 'Who really brings migrants to Italy "phantom landings"', www.northerworld.com, 8 July 2019, accessed 8 January 2020.

${ }^{14}$ M. Cantarella, 'Migranti. La strategia dei 'porti chiusi' non ha ridotto partenze e morti', www.avvenire.it, 8 January 2020.

${ }^{15}$ M. Villa, E. Corradi, and A. Villafranca, 'Fact Checking: Migrazioni 2018', www.ispionline.it, 7 May 2018, accessed 14 December 2019.

16 'Cruscotto Statistico Giornaliero', www.libertaciviliimmigrazione.dlci.interno.gov.it, 31 December 2019, accessed 8 January 2020.

${ }^{17}$ M. Villa, 'Fact Checking: Migrazioni', www.ispionline.it, 29 June 2017, accessed 8 January 2020.

${ }^{18}$ M. Villa, 'Italy Receives More Asylum Seekers from Germany than from Libya', 25 July 2019, accessed 14 December 2019.

${ }^{19}$ A. Magnani, 'Salvini accusa l'Europa ma boicotta le riforme per evitare altri casi "Sea Watch"', www.ilsole24ore.com, 30 June 2019, accessed 8 November 2019.

${ }^{20}$ F. Caccia, 'Donatella Tesei, l'avvocato Che Ha Fatto l'impresa Dopo Il Patto Di Natale Con Salvini', www.corriere.it, 27 October 2019, accessed 8 November 2019.

${ }^{21}$ A. Iannuzzi, 'Immigrazione, Lega, Pd: così poche centinaia di profili polarizzano il dibattito politico sui social', www.repubblica.it, 20 May 2019, accessed 8 January 2020.

${ }^{22}$ F. Bailo, 'Il successo della Lega, i media e le crisi migratorie', www.youtrend.it, 6 November 2019, accessed 8 January 2020.

${ }^{23}$ Despite the first decree having been converted into law by the Italian Parliament in December 2018, it was mainly implemented in 2019, which justifies our decision to cover it in depth in this article.

24 'Il decreto Sicurezza approvato con la fiducia: 336 sì alla Camera', www.repubblica.it, 27

November 2018, accessed 8 January 2020.

${ }^{25}$ M. Villa, 'I nuovi irregolari in Italia', www.ispionline.it, 18 December 2018, accessed 8 January 2020.

${ }^{26}$ C. Torrisi, 'The Italian Government Has Approved a New Bill Targeting Migrants', www.openmigration.org, accessed 8 January 2020.

${ }^{27}$ J. Horowitz, 'Italy's Crackdown on Migrants Meets a Grass-Roots Resistance', www.nytimes.com, 1 February 2019, accessed 8 January 2020.

28 'Stop Dei Giudici al 'decreto Salvini'. Il Leader: Sentenza Vergognosa, Faremo Ricorso', www.corriere.it, 3 May 2019, accessed 8 January 2020.

${ }^{29}$ C. Del Frate, 'Corte Ue: no al rimpatrio di un rifugiato politico anche se commette reati', www.corriere.it, 14 May 2019, accessed 8 January 2020.

${ }^{30}$ The letter is available at: http://www.giurisprudenzapenale.com/2019/08/08/decreto-sicurezza-bisil-presidente-mattarella-promulga-la-legge-ma-scrive-ai-presidenti-di-senato-camera-e-consiglio-deiministri/

31 'Mattarella Signs New Security Decree, While Raising Issues about It', www.ansa.it, 8 August 2019, accessed 8 January 2020.

${ }^{32}$ L. Tondo, 'Italy Adopts Decree That Could Fine Migrant Rescuers up to $€ 50,000$ ', www.theguardian.com, 15 June 2019, accessed 8 January 2020.

${ }^{33}$ M.T. Meli, 'Ora Zingaretti chiede un 'cambio' a partire dal decreto sicurezza', www.corriere.it, 19 September 2019, accessed 8 January 2020.

${ }^{34}$ A. Ziniti, 'Decreto sicurezza, il Tar del Lazio sospende il divieto di ingresso in acque italiane. La Open Arms si dirige verso Lampedusa. Salvini firma il nuovo divieto', www.repubblica.it, 14 August 2019, accessed 8 January 2020.

${ }^{35}$ M. Villa, 'I nuovi irregolari in Italia', www.ispionline.it, 18 December 2018, accessed 8 January 2020. 
${ }^{36}$ Cima, R, and L. Ricolfi, 'Criminalità in Italia', www.fondazionehume.it, 2015, accessed 8 January 2020.

${ }^{37}$ M. Villa, 'I nuovi irregolari in Italia', www.ispionline.it, 18 December 2018, accessed 8 January 2020. 